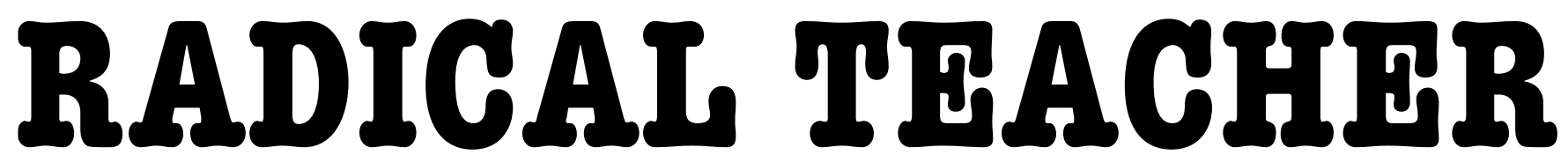
A SOCIALIST, FEMINIST, AND ANTI-RACIST JOURNAL ON THE THEORY AND PRACTICE OF TEACHING

\title{
Myths of Gender: Biological Theories About Women and Men
}

(RADICAL TEACHER NO.37, 1990)

by Saul Slapikoff

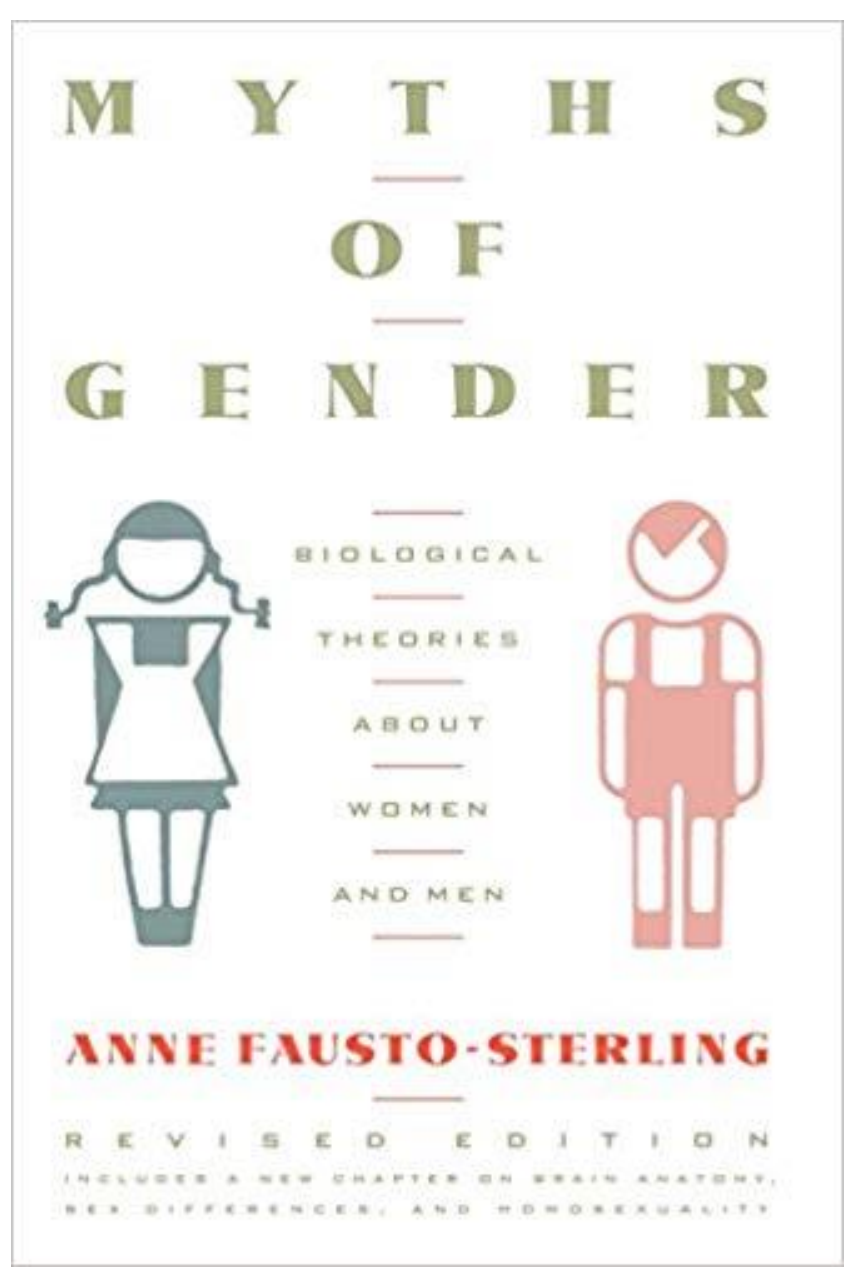

MYTHS OF GENDER BY ANNE FAUSTO- STERLING (BASIC BOOKS, 1985) 
Myths of Gender: Biological Theories About Women and Men. Anne Fausto- Sterling. Basic Books.

A

bout a third of my course "Contemporary Biosocial

Problems" deals with issues of how biologists deal

with issues of gender. Since half of the students in the class are non-science majors and the rest biology majors, there has always been some difficulty in finding readings that address the former group of students without patronizing the latter. For the most part, the books that I have used in the past have been perceived as too difficult by the non- science majors. Now, fortunately, Myths of Gender is available. My students, regardless of major, have loved using Fausto-Sterling's book because of its easy readability and clear explanation of biological concepts that in the past students have found difficult. To quote one art history major:

The Fausto-Sterling book is the one I've been waiting for: it's like a God-send. She presupposes virtually nothing on the part of the reader, and yet it is a substantive, well-researched work. She presents the vital scientific background without going into detail ad nauseum, as well as thorough, comprehensible statistical information which facilitate[s] understanding how she ... goes about building or taking apart arguments. (Devan Paillet)

Focusing on the role of ideology in science, FaustoSterling critically examines research in areas such as gender and brain organization; genes and gender; hormones and menstruation, menopause, and aggression; and sociobiology. I can imagine Myths of Gender being a key text in courses that deal with gender through a variety of disciplinary approaches.

(cc) EY-NC-ND

ULLS D-Serle
This work is licensed under a Creative Commons Attribution-Noncommercial-No Derivative Works 3.0 United States License.

This journal is published by the University Library System of the University of Pittsburgh as part of its D-Scribe Digital Publishing Program, and is cosponsored by the University of Pittsburgh Press. 